\title{
Public service broadcasting (PSB) regulation in Indonesia: Between market and public interest
}

\author{
Masduki, ${ }^{l, *}$ \\ ${ }^{1}$ Senior Lecturer, Department of Communication, Universitas Islam Indonesia, Yogyakarta, Indonesia
}

\begin{abstract}
The reform of public service broadcasting (PSB) faces many obstacles in countries with political transition such as Indonesia. After 1998-political change, the arrival of ideas to establish PSB in Indonesia in two decades lacks of appropriate policies. As in other transitional states in Eastern Europe, there is the lack of regulatory design as well as its implementation. This paper examines process of formulating PSB law in 2002, particularly pays attention to industry capture over the making process as a critical tool to observe a long-controvercial of broadcasting law revision process in Indonesia (2012-2016). By use public interest and capture theories in regulation, this paper answers why the outcome of PSB regulation is weak by observing how the law was made. This study provides new analysis on PSB media law that still rare in Indonesia. As independent and non-profit body, Indonesian PSB represented by RRI (Radio of the Republic Indonesia) and TVRI (Television of the Republic Indonesia) is protected by Broadcasting Act.32/2002. It was enacted in favor of two actors: authoritarian officials with interest to use PSB as their mouthpiece in one side and the industry groups with interest to apply free market policy on the other.
\end{abstract}

\section{Introduction and Research Design}

As a public policy, redesigning public service broadcasting (PSB) regulation in the world is a complex negotiation process, influenced by political system and the strength of economic and social culture of a country. For instance, change in political system from authoritarianism to liberal in transitional countries in Europe and Asia has a direct effect on the process of formulating new media laws, actors involved and the result. It is mostly indicated by contradictory policy outcome between public and private interest.

Historically, follow the change of political system in Eastern Europe (late 1980s) and in Asia (late 1990s) from authoritarian and communist to liberal democratic system, PSB experienced significant regulatory reform. In line with the above radical reform, in the last 20 years, there was a trend of policy changes that move PSB ownership from state into independent public service media [1]. Furthermore, the changing PSB policy is a direct response to the emergence of new technology [2].

\footnotetext{
${ }^{*}$ Corresponding Author: masduki@hotmail.com
} 
The political reform 1998 which marked by the end of Suharto power (1966-1998) has triggered media system reform in Indonesia [3]. For example, there was public pressure to reform RRI and TVRI amidst rapid growth of commercial media outlets. Prevously (19961998), media system was authoritarian in nature which both RRI and TVRI was state owned media and operated as a mouthpiece of the regime.

One of the important regulations born after the reform 1998 was Broadcasting Law no. 32/2002 which recognizes Public Service Broadcasting (PSB) and replaces the old Broadcasting Act no. 24/1997. The Act has formally changes the ownership status of RRI and TVRI from state to public. However, compare to similar policy in developed countries such as Germany and the UK, the Act is not clearly explaining structure, funding mechanism, content criteria and the ways that guide transformation from old to the new PSB system. Why?

In article 'Researching Public Service Broadcasting', Moe and Trine explains four types of PSB studies, namely policy, institutional, role of PSB in democratic life and post modern research. Since PSB is dependent on decisions within political realism, much research has focused on policy type, mainly in the regulatory governance [4]. I classify this paper as study of PSB governance policy in Indonesia.

This paper examines process of formulating PSB policies in Broadcasting Act of 2002 and pays attention to industry capture as critical tool for the similar process in the recent years. This study proposes as best practice for media advocates in managing their advocacy in the 2016-Broadcasting Law revision. I will look at PSB regulatory outcome in the Broadcasting Act as starting point and to limit this study, I will select four debates: legal status of PSB, structure, service area and funding system among actors and it will be explained in these two periods: agenda setting/first discussion (1998-2000) and negotiation/decision making phase (2000-2002).

This paper answers two questions: First, how are debates among stakeholders on PSB and to what extent it was formulated in the Broadcasting Law? Second, how and why the existing media industry captured the PSB regulation? Broadcasting Act no. 32/2002 will be a primary document to analized, followed with other documents such as articles in journals, books and other literatures. My last observation in years 2000-2002 would also enrichs while other PSB policy model especially in Europe and the US will be used for comparison.

\section{Theoretical Frameworks}

\subsection{PSB Regulatory Governance}

PSB is widely understood as broadcasting made, financed and controlled by the public, for the public. According to UNESCO researchers, it is neither commercial nor state-owned and free of political interference and pressure of commercial forces [5]. In order to ensure above condition, Smith stated PSB regulatory governance should meet the followings: (a) legislative regulatory framework for its sustainable development; (b) clear mandate for public service broadcasters; (c) exact remit and standard of content; (d) corporate and financing structure that ensure editorial independence; (e) mechanism for public accountability and (f) role to meet global challenges: digital and transnational broadcasting [1].

In legal status, most of PSB regulated as independent entity to guarantee as public asset in safeguarding the interests of cultural, political democracy and to balance the increasing commercial media. For instance, BBC and ARD (Germany) are independent Corporations. Furthermore, to ensure the importance of this issue, the European Union imposes 
Amsterdam Protocol of 1997. This regulation forced former Eastern Europe states that joined the Union to change their regulations and old-authoritarian form of PSB [6].

In Indonesia, political and economic crisis bring PSB regulatory issue to more complex one. Debates on PSB policy occur between both, the desire to create new rules to protect public interest by law in one side with desire to avoid strick rules resulted from historical and political trauma of authoritarian sytem in the past [7]. Amid the strengthening capitalist broadcasting industry, debates on PSB legal status, structure and funding which involved government, industry and civil society took long time. Recently, commercial radio and TV which controlled by monopolistic corporation [8] became the main enemy to establish public service media. To protect their power, commercial sectors actively try to limit PSB regulatory governance.

\subsection{Public Interest in Broadcasting Sector}

Normally, two issues: frequency scarcity and cultural porposes is classical rationales for PSB regulation. As a public domain, frequency is technically limited. For example, if it is used by any radio or TV company, the other can not use it at the same time. Hence, in the name of public and its limitation, frequency should be allocated for majority of the public, and the licensing process based on competitive roles, involves independent regulator (9). There is a general view that frequency should not be utilized by only government and industry players, but also for the benefit of citizen. Although the frequency scarcity doctrine is no longer valid at this time, its regulatory legacy still lives on the so-called "public interest" requirements over broadcasting contents. This commanded to satisfy public interest, convenience, and necessity [9].

Moreover, cultural protection over social impact from television/radio content is the other reason why broadcasting is strictly regulated [10]. Broadcasting that is free to air has entered private sphere of citizen at all social and economic levels. All over the world, radio and television are two major media which people can access news and entertainment, and are often regarded as the powerful media.

Basically, the term 'Public Service' is the central point of necessary regulation for PSB at national and international level. Public service is used to describe a kind of provision deemed vital for every member of society, regardless of spending power, educational, social geographical location, or gender. At different times in different polities, varied services have belonged to this category, from public infrastructure like roads or telephone lines, via health care, to education as well as radio and television broadcasting [4]. In the liberal states such as the UK, in addition to market failure in distributing public resourse, PSB policy is a form of state's obligation to provide a public sphere [11]. Four aspects: legal status, structure, service area and the provision of PSB fund are the central policy debates that reflect degree of adoption to public interest in the PSB law.

\subsection{Capture Theory of Regulation}

As stipulated in Law no. 12/2011 on law making mechanism, formulation of national act in Indonesia is an absolute authority of both parliament and government officials. Hence, the legislator or government is policy maker. Unlike in the EU, Indonesia officials does not establish a permanent external agency or gives mandate to outside body to draft of a policy. Nevertheles, parliament may invite some experts as temporary consultant. By this power, issuing law draft formally should come from both government and parliament, through various steps. Civil society as well as industry may propose a draft to both institutions. In the formulation process, parliament formed a special team consist of 
parliament members that represent political parties. The team intensively organizes both internal meetings and public hearings prior to the enactment of a law.

According to Barry M. Mitnick, problem in the regulatory making process arises when a policy maker (for Indonesia: Parliament or Government officials) acts in the industry side to damage public interest. It means, their policy outcome captured by industry as privateregulated party [12]. For instance, the agency's main mandate to regulate PSB to maximize benefit of society is captured and the agency acts in favour of the industry interest due to their lack of knowledge on the broadcasting system in the policy making process. Indeed, to regulate PSB system, policy makers require specific knowledge such as frequency allocation; remit, and funding system. Mitnick describes six forms of capture: constitutional; systemic; relational (governance); individual; functional and chronical [12]. For this study, I will explain two forms: individual and functional.

First, individual form: incentives shape decision making between legislators and the industry [12]. In the electoral system with high economic cost, capture occurs as a form of 'political barter' among political parties and their politicians in one side and corporate donors on the other. In this model, regulatory members cum politicians need campaign funds to encrease their voters. The industry can easily provide 'political investment' fund for them in order to have room to influence legislative policy outcomes of the policy makers in the future. Second, functional. It happens when regulated parties control and filter information essential to policy decision making, actively suply information that manipulate public opinion in order to keep their interest [12]. For instance, present on hearings intensively, active responses to the need of data, opinion spin in media and the involvement of industry expert as a temporary consultant of parliament.

In the long history of media reform, government, politician and independent commission of broadcasting are vulnerable bodies to intervere. For example, the scandal of internet neutrality regulation applied by Federal Communication Commission, the United States independent body [19]. In case of Indonesia, before ratification of the Broadcasting Act of 2002, the discussion and encatment of the Telecommunication Act of 1999 was also influenced by national and international telecommunication industries. They intended particularly to remove barriers for foreign investment in telecommunication market [13].

\section{Debates on Indonesian PSB}

In this part, I will explain result of document analysis, mainly Broadcasting Act of 2002 and its related documents enriched by my field observation in the past (2000-2002). During 1998-2002, there is strong debate among government, industry and public in the process of formulating the Act. Government interest represents by Ministry of Communication and Information Technology (MCIT), while Association of Indonesian Private Television (ATVSI) represents industry group. Meanwhile, public interest was voiced by various parties: academics of Indonesian University and some non-government organizations such as Indonesian Press and Broadcasting Society or MPPI [14]. In this situation, Parliament members tried to accommodate all opinions equally, but sometime falled in to one party interest. The table below desribes various proposals from all above parties over four issues of PSB governance: legal status, structure, service area and funding sources.

Table 1. Proposals on PSB Governances

\begin{tabular}{|c|c|c|c|c|}
\hline No & Issues & Government & Industry & Public \\
\hline 1 & Legal status & $\begin{array}{c}\text { State agency under } \\
\text { MCIT. A state agency } \\
\text { under ministrial office } \\
\text { and it established by }\end{array}$ & $\begin{array}{c}\text { State owned } \\
\text { corporation, a } \\
\text { commercial entity } \\
\text { under ministry of }\end{array}$ & $\begin{array}{c}\text { State agency, } \\
\text { independent, public } \\
\text { owned, non-profit and } \\
\text { it established by state }\end{array}$ \\
\hline
\end{tabular}




\begin{tabular}{|c|c|c|c|c|}
\hline & government & state own corps & in the name of public \\
\hline 2 & $\begin{array}{c}\text { Governing } \\
\text { structure }\end{array}$ & $\begin{array}{c}\text { Board of supervisory } \\
\text { and board of executive } \\
\text { under MCIT, elected by } \\
\text { MCIT }\end{array}$ & $\begin{array}{c}\text { Board of } \\
\text { commissary and } \\
\text { executives as in the } \\
\text { private corporation }\end{array}$ & $\begin{array}{c}\text { Board of supervisory } \\
\text { and board of executive } \\
\text { as in the BBC, elected } \\
\text { by parliament }\end{array}$ \\
\hline 3 & Service area & $\begin{array}{c}\text { Covers the entire } \\
\text { Indonesian archilepago } \\
\text { with proportional } \\
\text { allocation of frequency } \\
\text { between public, private } \\
\text { and community } \\
\text { broadcasting }\end{array}$ & $\begin{array}{c}\text { Covers area that is not } \\
\text { covered by } \\
\text { commercial service, } \\
\text { use only the existing } \\
\text { frequency allocation }\end{array}$ & $\begin{array}{c}\text { Covers the entire } \\
\text { Indonesian archilepago } \\
\text { accompanied by local } \\
\text { public service } \\
\text { broadcasting, }\end{array}$ \\
\hline 4 & $\begin{array}{c}\text { Funding } \\
\text { sources }\end{array}$ & $\begin{array}{c}\text { State budget, lisence } \\
\text { fee, social donation, } \\
\text { pommertion of frequencies }\end{array}$ \\
& and other appropriate \\
ancomes & $\begin{array}{c}\text { State budget, lisence } \\
\text { fee, social donation, } \\
\text { strick limitation of } \\
\text { commercial } \\
\text { advertising }\end{array}$ & $\begin{array}{c}\text { Lisence fee, state } \\
\text { budget, social } \\
\text { donation, commercial } \\
\text { advertising and other } \\
\text { appropriate incomes }\end{array}$ \\
\hline
\end{tabular}

Source: $[7,14]$

All debates influence over the making period of Broadcasting Act that spends more than 6 years from its agenda setting and drafting in the last 1997 up to the formal enactment in the parliament by November 28, 2002. On the PSB side, the result of these debates was contradicts to public interest. From all 64 articles in the Law, PSB sector is regulated only in 5 articles. First, article 13 that states PSB as one of four types of broadcasting institution in Indonesia alongside private, community and pay model.

Second, article 14 that explain legal status, PSB mandate and its structure. This article describes PSB as law entity established by state, operated as independent, neutral and not for commercial interest, and its function to serve society. This article also states clearly that RRI and TVRI are choosen for PSB in one side and provides room for establishment of local PSB outside both institutions on the other.

Third, article 15 explains funding sources (ranging from license fee, state annual budget, social donation, advertising and other appropriate incomes connected to broadcasting) and role of finance accountability (finance report should be audited by public accountant, published on media). Fourth, the two articles that regulate PSB's content: PSB to broadcast programs from internal country for $60 \%$ at minimum a day; time allocation of business advertising (maximum $15 \%$ ) and social advertising (minimum $30 \%$ ) of the entire duration a day.

The enactment of these 5 articles indicates three conditions in favour for public interest. First, adoption of BBC-like model of independent and public owned PSB, changing RRI and TVRI's legal status from state to public entity. Second, introduction of lisence fee as source of funding alongside state budget is a sign for public based PSB and public participation. Third, establishment of supervisory board elected by parliament is a symbol for formal public access to the PSB operation that was not applicable in the past.

However, policy of service area, frequency allocation and advertising are in favour of market interest. As described above, the Act limits PSB to broadcast commercial advertising up to $15 \%$ of the entire time a day. This followed by two government decrees of 2005 (translation of Broadcasting Act) that limit frequency for PSB up to $20 \%$, compare to private that receive $75 \%$. Limitation of commercial Ads as funding source will potentially disturbs PSB's sustainability, especially in the crisis of state budget and license fee as ideal fundings. Also, limitation of frequency reduces opportunity to develop new PSB channels in order to wider public services.

Based on these weaknesses, I argue there will be no significant reform of RRI and TVRI as PSB to reach audiences as citizen and create public service. To compare, before 
enactment of the Law, RRI uses only about $15 \%$ of frequency allocation. The rest is in power of private radio stations. Since year 1989, commercial televisions utilize about $95 \%$ of the entire TV frequencies while TVRI only use 5\% [7]. Overall, the application of two articles of the Law will place PSB as a minor player in the audiences compare to private firms.

Furthermore, as discussed above, from the 5 articles, there is no detail explanation of PSB institutional design compare to specific PSB law as in the developed country. According to eight indicators developed by Smith [1] it only adopts 4 indicators and needs more articles to adopt the rest in the same level of regulation. For instance, more regulation needed to exact remit and standard of PSB content, finance that ensures editorial independence as well as the mechanisms to enhance public monitoring over the entire operation.

\section{Captured by Industry}

This section describes captures of industry power over formulation of PSB articles in the two periods: agenda setting (1998-2000) and negotiation/decision making phase (20002002). To define, agenda is the list of issues in a polity, consists of both political (the list of issues from decision-makers) and public agenda (the list of issues from general public) [15]. Decision making is a final choice, an outcome of cognitive processes leading to the selection of action among several alternatives [16]. I will start by explaining actors involved in the policy making period and the dynamics of their interaction.

During agenda setting and negotiation phases (1998-2002), Arifuddin [17] described enthusiasm of three actors: parliament members; officials under two presidents: Habiebie and Gus Dur and civil society to birth a new law which replaces old-Broadcasting Act no. 24/1997. In the ideological perspective, there are three kinds of actor: pro democratic broadcasting (CSO), authoritarian broadcasting system (Government) and pro liberal media system represented by them [18]. Furthermore, Irma [14] explained three different groups: (1) private firm that intend to protect their domination in the market. At agenda setting process, introduction of PSB in the draft was prevented by industry, (2) civil society such as the Alliance of Indpendent Journalist and academics from Indonesian University which proposed PSB institution in broader context than only as state agency. In their view, PSB may be a community based stations, (3) government (via MCIT) that proposed PSB system under MCIT. It was contrary to general idea of independent PSB in the parliament and CSO [14].

Compare to civil society, the industry's lobby to policy maker is more intensive involved a wide range of collaboration among ATVSI, advertising agencies, production houses and broadcaster associations. It includes regular opinion publication in their own media; propose law draft, and personal approaches to politicians. In contrast, civil society with limited support from RRI and TVRI broadcasters and international agencies focuses only their move to public opinion through community media, grassroot level of discussion and mass rally.

During 2000-2002, in summary, capture by the industry over PSB law took place in two steps: (1) agenda setting step, ability to setting up the central issue, (2) negotiation phase, ability to influence policy maker to accept policy in favour of their interest. From media coverages and notes of my field investigation in the past (years: 2000-2002), refer to Mitnick [12]. I found at least two kinds of capture below.

In the agenda setting, the industry applied functional model. With their highest resources of knowledge, fund and media outlets, private TV and radio owners with their professionals develop massive opinion to promote the importance to protect private industry as key actor in economic growth. Via more than 7 national TV channels such as 
RCTI, Indosiar and ANTV, ATVSI published regular news, talkshow and advertisements. At the same time, ATVSI provides data and invite experts to set a law draft favouring the goal, and actively sends experts to public hearings in the parliament or discuss with government officials.

The long history of close-relation between private TV owners and political leaders obviously established common goal and influence outcomes of policy maker which depend on the direction from their party leaders. In Indonesia, political party needs good image and politicians need their safety in the parliament. The industry provides it by managing politician's images in the public though massive news coverages. This can be identified as individual incentive model [12] although more evidences are needed to ensure this practice.

Analyzing series of statements from ATVSI and PRSSNI (association of private radio owners), I conclude the main goal of their capture is protection of their companies, in the name of millon workers, high investment of broadcasting equipment and their claim of public utilily over contents. Hence, they criticize intiative to regulate PSB in the form of state intervention. Improvement of PSB was seen as 'serious danger' for their two sectors: huge area of audience service and advertising market incomes. Having the widest network, RRI and TVRI as PSB will be a strong competitor for the industry [7].

In negotiation and decision making phase, the firms adopt similar model with the agenda setting with more intensive pressures. Aside of actively attend public hearings and gathering mass rally, they influence both parliament and MCIT officials through direct meetings outside offices. Finally, in respond to the enactment of Act on 28 November 2002 which recognize independent broadcasting commission as their new regulator, the Industry raise protest by airing 'dark colour' in their TV stations which symbolizes a death of press freedom.

\section{Conclusion}

This paper shows that PSB debate in the policy making process in Indonesia during 1998-2002 has been intense. Actors separate into three groups: government, industry and civil society. There is unequal position which the industry has more resources to create pressure over policy makers in favour of their dominant in the market place than civil society. Formally, Broadcasting Act 32/ 2002 recognizes PSB as independent and public owned body. It is followed by introduction of public access to the supervisory body and parliament right to its selection process and to supervise PSB operation in the interest of public. However, there is no appropriate policy to ensure sustainable improvement of PSB management. The two policy sectors: limitation of Ads and frequency are obviously in favour of the industry. Hence, in terms of public interest, the regulation is very weak.

In my observation, this was a result of industry capture over the law making process. The goal of this action was mainly to keep PSB as a minor broadcasting actor in the field and maintain capitalist players that were already dominant. To sum up, I would like to address two possible solutions: First, Broadcasting Act no. 32/2002 needs to revise. Concerning the huge sectors involve in the revision process which will spend long time and energy, the 2015-proposal from parliament to draft specific law of PSB can be a faster way to accelerate PSB policy reform. Second, improvement of knowledge of policy makers on PSB governance is a central in managing public interest in the process of both the law revision and addressing new specific PSB law.

Finally, to prevent industry's capture in upcoming PSB law revision, strong alliance is needed amog local and international advocates in the process of regulatory making and its implementation. A model of supranational intervention such as European Union to the 
national policy of PSB can be adopted by ASEAN, a similar regional association of nations in South East Asia. However, in culture of secrecy, it is quite difficult to investigate deepcoalition among Indonesian politicians as policy maker with industry in the long period of policy making and its impact to policy outcomes. More research is needed on this particular issue in the future.

\section{References}

1. E. Smith, A Road Map to Public Service Broadcasting (UNESCO and AIBD, Kuala Lumpur) (2012)

2. I. Banerjee, Public Service Broadcasting, A Best Practices Sources (AMIC-UNESCO, Singapore) (2005)

3. Kristiawan, Media Liberalization, Political Economy of Democracy and Media Industrialization in Indonesia, (Indonesian University Publication, Jakarta) (2012)

4. H. Moe, T. Syvertsen, Researching Public Service Broadcasting, In K. Wahl, T. Hanitzsch (ed.), The Handbook of Journalism Studies (Routledge, London) (2009)

5. T. Mendel, Public Service Broadcasting: A Comparative Legal Survey (The Asia Pacific Broadcasting Development and UNESCO, Kuala Lumpur) (2000)

6. K. Jakobuwicz, Finding the Right Place on the Map, Central and Eastern European Media Change in a Global Perspective (Intellect Books, Bristol) (2008)

7. Masduki, Broadcasting Regulation, From Authoritarian to Liberal (Institute of Islamic and Social Studies, Yogyakarta, Indonesia) (2007)

8. M. Lim,@crossroads, Democratization and Corporatization of Media in Indonesia (Partisipatory MediaLab Arizona State University and The Ford Foundation, USA) (2011)

9. A. Thierer, Why Regulate Broadcasting? Toward A Consistent First Amendment Standard for Information Age (Communication Law Conspectus, Washington) (2005)

10. J. Dominick, Broadcasting, Cable, the Internet and beyond, an Introduction to Modern Electronic Media (McGrawHill Publishing, Boston) (2004)

11. J. Habermas, The Structural Transformation of the Public Sphere (Massachusetts Institute of Technology Press, Cambridge) (1991)

12. B. Mitnick, Capturing Capture: Definition and Mechanisms, In D. Levi-Four (ed.), Handbook of the Politics of Regulation (Edward Elgar Publishing, Cheltenham) (2011)

13. P. Rianto, National Private TV Domination, The Crisis of Ownership and Content Diversity (Pemantau Regulasi dan Regulator Media and Tifa Foundation, Jakarta) (2012)

14. W. Maimun Irma, Social Construction of Public Broadcasting, Political Economy Analysis of Broadcasting Act, 32/2002, (Indonesian University Publication, Jakarta) (2003)

15. J. W. Kingdon, Agendas, Alternatives, and Public Policies (Harper Collin Publication, New York) (1995)

16. F. Meyerhöfer, Agenda Setting and Decision Making in the European Union: The Case of Galileo (The Hertie School of Governance, Berlin) (2009)

17. Arifuddin, Finding Undisputed Truth, Broadcasting Reform in Indonesia (Nagoya University, Japan) (2014)

18. G. Heryanto, Power Relation within Legal Entity Changes of TVRI: A Political Economy Study (Indonesian University Publication, Jakarta) (2006)

19. R. Esguerra, The FCC and Regulatory Capture, https://www.eff.org, accessed on February 29, 2016 
Law Documents:

1. Broadcasting Act, No. 32/2002

2. Mechanism of law making Act, No. 12/2011

3. Government Decree on RRI and TVRI as Public Service Broadcasting No. 11 and $12 / 2005$ 